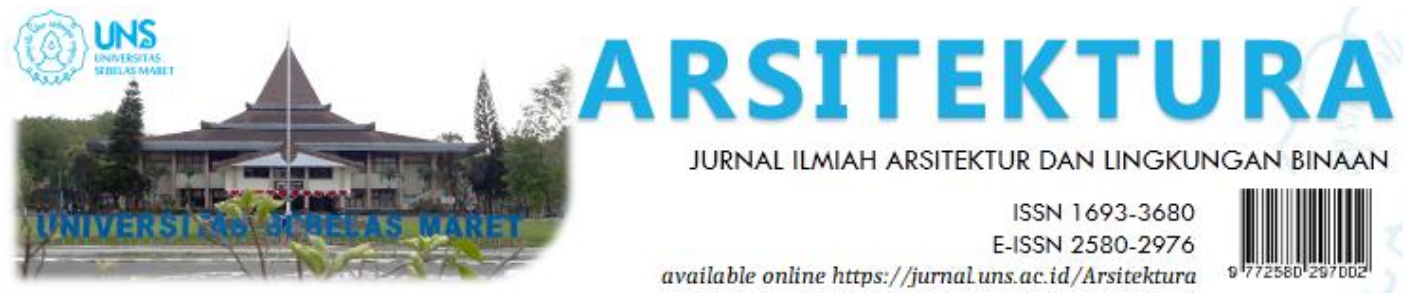

Volume 19 Issue 2 October 2021, pages: 249-262

\title{
Pendekatan Situasi Pro-Inovasi untuk Penelitian dan Pengabdian Masyarakat pada Pasar Desa di Kabupaten Majalengka
}

\section{Pro-Innovation Situation Approach for Research and Community Service at the Village Market in Majalengka Regency}

\author{
Agus Suharjono Ekomadyo ${ }^{1 *}$, Nurrohman Wijaya ${ }^{2}$, Hernadi ${ }^{3}$, Dinda Nadhila Augusta ${ }^{4}$ \\ Sekolah Arsitektur, Perencanaan, dan Pengembangan Kebijakan, Institut Teknologi Bandung, $1,2,3,4$ \\ ekomadyo@ar.itb.ac.id
}

DOI: https://doi.org/10.20961/arst.v19i2.50683

Received: April 26,2021 Revised: July 30,2021 Accepted: September 12,2021 Available online: October 30,2021

\begin{abstract}
This article is written based on research and community service (PPM) activities by University (PT) to encourage innovation in rural areas. University is an institution that is tasked with producing world-class knowledge, while still having a role to contribute to local problems in Indonesian society, including encouraging innovation in rural areas. The case of research and community service chosen was the revitalization and development of the Village Market in Majalengka, where local village heads, known as Kuwu, built networks to develop the village's resources to respond to economic growth in this area triggered by Kertajati International Airport. With a pro-innovation situation approach, PPM is designed at the same time to produce design work that is beneficial to society and scientific knowledge extraction. With the framework of the Actor-Network Theory (ANT), knowledge extraction is carried out by tracing the relationships that occur at each stage of PPM, to find out whether there is an expansion of the actor-network at the end of the activity. There are three important findings in the investigation of the perpetrator's network. First, there is a local ecosystem, namely the Kuwu forum, which can trigger various innovative ideas involving parties outside the village. Second, some mediators play a role in bridging the "university world" with the "village world". Third, expansion of the innovation network after activities occurs if they have internal factors, namely solidity of key innovators in the village, and external factors, namely networks owned by researchers that can be used by innovators in the village to develop existing potentials. For a pro-innovation situation to occur, a "design thinking" approach needs to be done in designing PPM activities as well as part of problem-solving and scientific knowledge production.
\end{abstract}

Keywords: Actor-Network Theory (ANT); design-thinking; Majalengka, rural innovation; rural market

\section{PENDAHULUAN}

Perguruan Tinggi mempunyai peran strategis dalam pengembangan inovasi karena kemajuan ilmu pengetahuan yang digerakkan oleh kegiatan penelitian dan pengembangan masyarakat berkorelasi dengan tingkat produktivitas dan daya saing masyarakat suatu bangsa. Sebagai agen produksi pengetahuan, Perguruan Tinggi diharapkan mampu menghasilkan pengetahuan yang bermanfaat seluas-luasnya, bahkan berkelas dunia. Beberapa Perguruan Tinggi di Indonesia punya 
potensi untuk menjadi Perguruan Tinggi Kelas Dunia (PTKD), dengan ciri-ciri publikasi jurnal bereputasi, paten berbasis pengetahuan bernilai ekonomi tinggi sebagai pemandu inovasi, dan alumni yang piawai memanfaatkan pengetahuan baru untuk menciptakan kemakmuran dan kesejahteraan berskala internasional (Salmi, 2009). Meski demikian, keinginan untuk menjadi PTKD tidak membuatnya menjadi terisolasi dari permasalahan lokal, justru bagaimana kontribusi terhadap permasalahan lokal bisa diangkat menjadi pengetahuan yang berkelas dunia (Dipojono, 2019).

Salah satu permasalahan lokal adalah kebutuhan akan inovasi di perdesaan. Sejak diberlakukannya Undang-Undang Nomor 6 tahun 2014 tentang desa, banyak desa mulai berupaya mengembangkan potensi wilayahnya, dan mencoba membangun jejaring dengan Perguruan Tinggi. Para civitas akademika Perguruan Tinggi diharapkan secara independen dapat memberikan kontribusi nyata menuangkan pemikirannya dalam upaya mendorong inovasi di desa dengan tetap memperhatikan karakter dan modal sosial yang ada (Barki dkk., 2017) (Yuliawati, 2017). Gagasan inovasi di desa mensyaratkan komunikasi dan interaksi yang baik dengan seluruh para pemangku kepentingan (Arumsari dkk., 2017) (Febriana dan Setiawan, 2016). Aneka inovasi, misalnya inovasi perencanaan dan penganggaran pembangunan atau inovasi anggaran dana desa akan berjalan dengan baik apabila terdapat komunikasi yang efektif dari kepala desa dan masyarakatnya (Hilman, 2016) (Sururi \& Mulyasih, 2017) (Annisa \& Widhi, 2018) (Nursetiawan, 2018).

Artikel ini ditulis sebagai suatu langkah peran Perguruan Tinggi dalam mendorong inovasi desa, dengan mengambil kasus Pasar Desa di Kabupaten Majalengka. Sejak pembangunan Bandar Udara Kertajati dan penetapan Segitiga Pertumbuhan Ekonomi "Rebana" (Cirebon Raya, Patimban, Kertajati), muncul berbagai gagasan agar bagaimana investasi infrastruktur itu mampu membawa kesejahteraan bagi masyarakat setempat (Althaf, 2019) (Damayanti, dkk. 2017) (Zulfikar, 2017). Beberapa komoditas lokal perdesaan seperti pertanian bisa terdampak akibat pertumbuhan ekonomi di kawasan ini (Jimika, 2019)
(Hidayat dan Sutandi, 2014). Melihat potensi ini, beberapa kepala desa di Majalengka, yang dalam bahasa lokal disebut Kuwu, mencoba membangun komunitas agar bagaimana potensi desanya bisa berkembang akibat perkembangan kawasan Majalengka. Kasus Pasar Desa dipilih, karena pasar diakui sebagai rumah ekonomi dan rumah budaya bagi masyarakat Indonesia (Basri, dkk., 2010) (Ekomadyo dan Hidayatsyah, 2012) (Ekomadyo, 2019). Inovasi terhadap pasar diharapkan mampu menghasilkan aktivitas ekonomi dengan nilai budaya dan memberikan dampak sosial.

Penelitian dilakukan dengan pendekatan situasi pro inovasi (Yuliar, 2011). Dengan pendekatan ini, maka riset dirancang dengan dua misi sekaligus: memberikan kontribusi bagi masyarakat setempat dengan wujud desain Pasar Desa, dan juga mengekstraksi kerja desain menjadi pengetahuan terstruktur yang layak dipublikasikan secara akademis. Pelaku kunci dari kegiatan ini adalah tim PPM (PPM) dari ITB dan beberapa Kuwu di Majalengka sebagai mitra dan pengguna hasil PPM. Namun demikian, peran para mediator menjadi perhatian karena menyangkut terbangunnya ekosistem yang mampu menghasilkan aneka gagasan inovasi, aneka strategi implementasi, dan aneka pengetahuan yang diproduksi dalam kegiatan inovasi yang berlangsung.

\section{METODE}

Penelitian ini dilakukan dengan pendekatan situasi pro-Inovasi (Yuliar, 2011), yang melihat inovasi sebagai sebuah proses bagaimana jejaring-jejaring para pelaku inovasi bisa terbangun lewat aneka kegiatan penelitian, pengabdian masyarakat, dan sejenisnya. Model ini merupakan penyempurnaan dari model Triple Helix (Etzkowitz, 2008), dengan lebih rinci melihat aktor-aktor yang terlibat dalam suatu kerja inovasi. Dengan pandangan ini, jejaring antara peneliti dan non-peneliti ini memiliki banyak koneksi, pertemuan antara mereka akan menghasilkan ruang pembelajaran yang memungkinkan difusi hasil penelitian. Interaksi antara peneliti dan non-peneliti (pengadopsi hasil penelitian) membentangkan ruang pembelajaran secara kolektif. Situasi proinovasi dapat dibedakan dengan: 1) situasi antiinovasi, di mana peneliti membangun jejaring dengan komunitas peneliti namun terputus 
dengan jaringan non-peneliti, dan 2) situasi kontra-litbang iptek, di mana peneliti lebih sibuk dengan jejaring non-peneliti dan terputus jejaring pengembangan pengetahuan antara sesama peneliti (gambar 1).
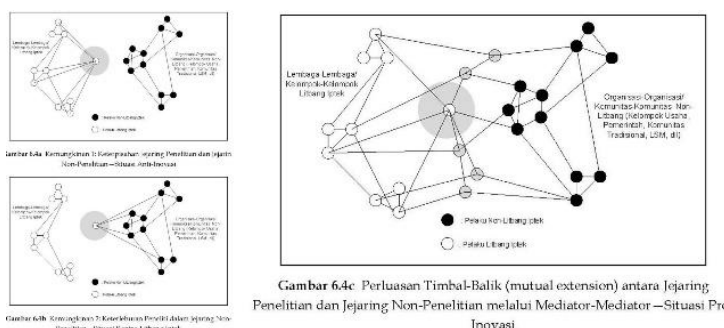

Gambar 1. Model Situasi Pro-Inovasi Sumber: Yuliar, 2011.

Konsekuensi pendekatan ini adalah riset dirancang sekaligus untuk menghasilkan desain pasar rakyat yang bisa dimanfaatkan pengguna namun juga mampu menghasilkan pengetahuan terstruktur selayaknya proses ilmiah. Lintasan dalam proses pengumpulan data ditata mana uang akan berorientasi pada hasil desain dan mana yang lebih diarahkan untuk ekstraksi pengetahuan. Agar punya nilai ilmiah, maka perlu ada teori yang digunakan untuk membaca data-data yang dikumpulkan selama proses merancang. Teori yang digunakan untuk penelitian ini adalah Teori Jejaring Aktor (Actor Network Theory/ANT), yang melihat suatu fenomena sosial sebagai sekumpulan aktor-aktor manusia dan aktor non-manusia yang terus bergerak (Latour, 2005) (Yuliar, 2009). Dengan teori ini, pengetahuan yang akan diekstraksi adalah sejauh mana relasi-relasi yang terbangun dalam tiap tahap kegiatan PPM. Dari sini bisa dirangkum pelaku-pelaku kunci apa saja yang berperan penting dalam orkestrasi jejaring dalam tiap desain. Pelaku kunci dalam kegiatan PPM tentang Pasar Desa di Majalengka ini adalah tim peneliti dari ITB dan beberapa Kuwu sebagai mitra pengguna riset. Namun, relasi-relasi yang terbangun juga melibatkan aneka perantara baik aktor manusia maupun aktor non-manusia, baik yang berperan sebagai mediator (aktor yang punya kehendak untuk membentuk jejaring) atau intermediari (aktor yang tidak punya kehendak dalam pembentukan jejaring). Pada akhir pembahasan, dilihat bagaimana rajutan yang terjadi antara jejaring pelaku Pasar Desa yang ada dengan jejaring dari peneliti. Dilihat juga apakah jejaring ini meluas atau tidak, berkesinambungan atau terputus, dan jejaring inovasi ini meluas, dan faktor-faktor apa saja yang mendorong terjadinya perluasan dan keberlanjutan jejaring setelah kegiatan penelitian ini selesai (gambar 2).

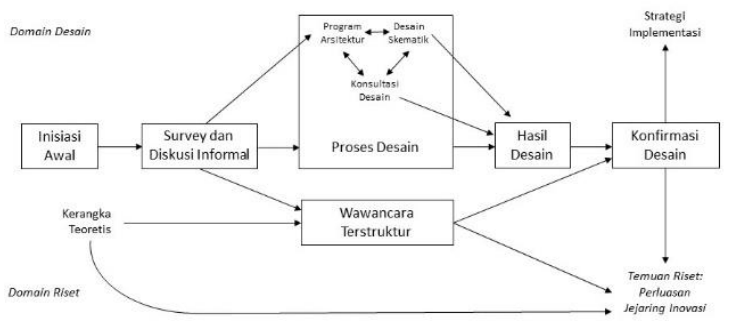

Gambar 2. Kerangka Penelitian

\section{HASIL}

Sesuai dengan pendekatan situasi pro-inovasi, maka hasil kegiatan PPM dirancang dalam dua bentuk: 1) karya desain, berupa rancangan pasar rakyat, yang diberikan ke masyarakat sebagai pengguna riset sebagai acuan untuk membangun pasar di desanya, dan 2) ekstraksi pengetahuan dari proses desain, untuk keperluan publikasi ilmiah yang dibagikan ke komunitas penelitian dalam kerangka produksi pengetahuan secara berkelanjutan. Dengan menggunakan pendekatan ANT, maka ekstraksi pengetahuan dalam proses desain dilakukan dengan melihat relasi-relasi yang terjadi dalam tiap tahap desain.

Dalam kegiatan PPM ini, tahap desain dipetakan ke dalam beberapa tahap, untuk kemudian dipetakan relasi-relasi yang terjadi. Tahap-tahap tersebut adalah: 1) relasi-relasi pada inisiasi awal, yaitu pada tahap awal gagasan hingga persetujuan proposal PPM, 2) relasi-relasi pada pengambilan data tahap pertama, yaitu diskusi informal dan survey lapangan, 3) relasi-relasi para pengambilan data tahap kedua, yaitu wawancara terstruktur, 4) relasi-relasi pada tahap proses dan hasil desain Pasar Desa, dan relasi-relasi yang berkembang pada tahap rekonfirmasi desain untuk dilihat mana jejaring inovasi yang meluas, tetap, atau menyusut atau setelah adanya kegiatan PPM.

Bagian ini menjelaskan analisis dan temuan penelitian atau proyek, yang orisinal. Pembahasan sangat direkomendasikan untuk mendiskusikan antara teori, peraturan maupun referensi yang digunakan dengan mendialogkan hasil penelitian yang diperoleh, sehingga mendapatkan temuan baru. 


\subsection{Relasi-relasi dalam Tahap Inisiasi Awal}

Sebelum muncul inisiasi tentang revitalisasi dan pengembangan Pasar Desa lewat PPM oleh Perguruan Tinggi, telah ada ekosistem inovasi untuk pembangunan kawasan perdesaan di Majalengka yang bersifat lokal. Beberapa kepala desa, disebut sebagai Kuwu, merasa perlu membangun jejaring bersama untuk merespon perkembangan Majalengka di masa depan setelah pembangunan Bandar Udara Internasional Kertajati. Forum ini dinamakan sebagai Forum Komunikasi Desa Kawasan (FKDK). Selain para Kuwu, ada dua mediator penting dalam perkembangan FKDK, yaitu seorang fasilitator pendamping masyarakat bersertifikat nasional yang kemudian memilih aktif ke kampung halamannya di Majalengka, untuk selanjutnya disebut fasilitator, dan civitas Perguruan Tinggi setempat, yaitu Universitas Majalengka (Unma).

Koneksi antara forum Kuwu yang bersifat lokal dengan ITB sebagai Perguruan Tinggi nasional antara lain didapatkan melalui koneksi dengan salah satu alumni ITB yang aktif dalam gerakan kemasyarakatan dan punya jejaring luas secara nasional. Awalnya, keberadaan alumni ITB ini, untuk selanjutnya disebut alumni, diminta FKDK untuk mendapatkan akses pengelolaan fasilitas di kawasan Bandara Kertajati. Alumni ini juga kemudian membangun koneksi dengan peneliti untuk sama-sama merespon perkembangan di Majalengka lewat sumber daya keilmuan yang ada di ITB. Isu Pasar Desa menjadi pilihan karena rekam jejak peneliti sekaligus jejaring peneliti dengan program revitalisasi pasar rakyat di tingkat nasional maupun provinsi Jawa Barat.

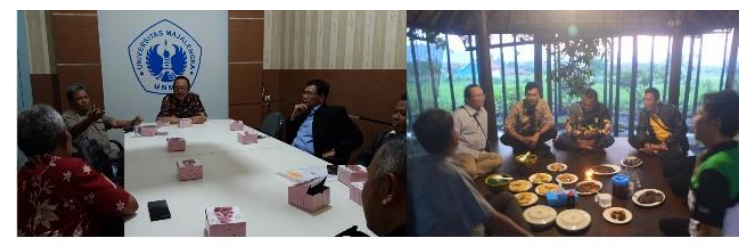

Gambar 3. Pertemuan perdana peneliti dengan Kuwu-Kuwu di Majalengka yang dimediasi oleh fasilitator, civitas Unma, dan alumni

Pasar Desa yang paling awal dipilih untuk direvitalisasi adalah Pasar Desa Maja Utara. Pasar ini dipilih saat pertemuan FKDK dengan peneliti, di mana para Kuwu menceritakan produk unggulan desanya masing-masing, dan Kuwu Maja Utara mengajukan Pasar Desa yang dikelola, yang juga punya keunikan karena adanya pasar ternak mingguan di tempat ini. Oleh peneliti, usulan ini ditindaklanjuti dengan survey ke lokasi pasar, untuk dijadikan bahan proposal program pengabdian masyarakat pada tingkat nasional (gambar 4 kiri). Pada saat visitasi proposal, peneliti didampingi oleh para Kuwu beserta aparat, fasilitator, dan civitas Unma, sehingga menunjukkan dukungan pemangku kepentingan untuk program yang diusulkan (gambar 4 kanan). Kekuatan dalam merajut pemangku kepentingan disebut sebagai salah satu nilai lebih proposal.

Inisiasi revitalisasi Pasar Desa kemudian menarik Kuwu lain untuk ikut berpartisipasi. Yang pertama adalah Kuwu Argamukti, sebuah desa yang kaya akan pertanian sayur mayur. Dalam diskusi antara Kuwu, peneliti, dan fasilitator, diinisiasi untuk membuat pasar distribusi sayur mayur dari desa Argamukti dan desa-desa lain dalam satu kecamatan, dengan usulan lokasi pada tanah milik Desa Sukasari Kaler yang kebetulan mempunyai akses yang lebih baik dari desa-desa lain, dan pasar yang diinisiasi ini dinamakan Pasar Argapura merujuk pada kecamatan yang menjadi lokasi dan cakupan pelayanan pasar (gambar 5 kiri). Yang kedua adalah Kuwu dari Desa Pasir Ayu, yang mengusulkan Pasar Desa berskala kecamatan, yang berlokasi pada desa di sebelahnya, yaitu Desa Sangkan Hurip, karena pertimbangan aksesibilitas yang lebih baik, dan pasar yang diinisiasi ini dinamakan Pasar Sangkan Hurip merujuk pada lokasi desa tempat pasar tersebut (gambar 5 kanan). Kedua Kuwu tersebut mempunyai kepemimpinan menonjol, keduanya merupakan koordinator untuk masing-masing kecamatan. Hasil diskusi antara peneliti, fasilitator, dan para Kuwu menjadi bahan untuk pengajuan proposal Riset ITB.

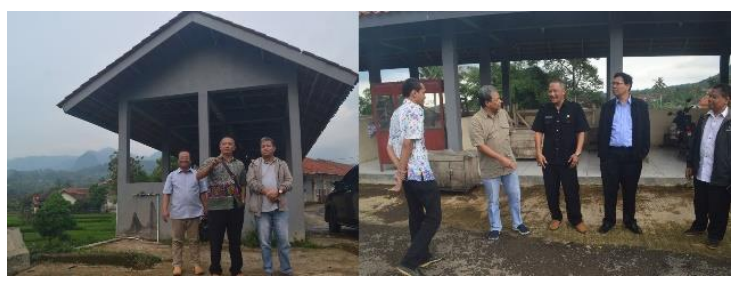

Gambar 4. Kunjungan peneliti ke lokasi Pasar

Desa bersama Kuwu (kiri) dan visitasi proposal di lokasi pengabdian masyarakat (kanan) 


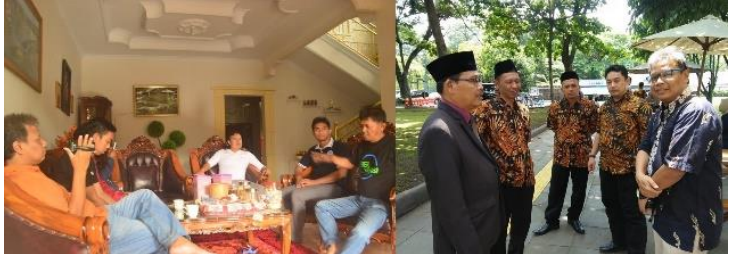

Gambar 5. Diskusi antara peneliti dengan Kuwu Argamukti untuk inisiasi Pasar Argapura (kiri) dan Kuwu Pasir Ayu untuk inisiasi Pasar Sangkan Hurip (kanan)

Dalam tahap inisiasi awal, terlihat peran penting relasi antara peneliti dengan para Kuwu dalam terciptanya inisiasi tentang revitalisasi dan pengembangan Pasar Desa lewat kegiatan PPM. Ada beberapa mediator yang berperan dalam terbangunnya jejaring pada tahap awal inisiasi, yaitu alumni yang menghubungkan antara peneliti dengan fasilitator, fasilitator yang merajut aspirasi para Kuwu dan memetakannya sesuai dengan konteks proposal yang akan diusulkan peneliti, dan civitas Unma yang menjembatani diskusi antara para Kuwu dengan pihak dari luar Majalengka termasuk alumni dan peneliti. Artinya, ada ekosistem yang bersifat lokal di Majalengka yang mendorong aneka inisiasi gagasan inovasi yang melibatkan pihak-pihak luar.

\subsection{Relasi-relasi dalam Tahap Diskusi Informal dan Survey Lapangan}

Seperti sudah dijelaskan, konsekuensi situasi pro-inovasi dalam kegiatan PPM adalah pengumpulan data yang dilakukan dalam dua tahap. Tahap pertama adalah pengumpulan data untuk keperluan luaran penelitian dalam bentuk karya desain. Di sini, pengumpulan data digunakan untuk menelusuri permasalahan dan merumuskan tujuan desain, yang termasuk lingkup dalam kegiatan pemrograman arsitektur (Pena, 1977, Palmer, 1981, Duerk, 1993).

Pengumpulan data tahap pertama melibatkan semua tim peneliti, yaitu peneliti, anggota peneliti, dan asisten peneliti, beserta pelakupelaku lokal yaitu fasilitator, para narasumber yaitu pelaku-pelaku yang terkait dengan pasar, dan para surveyor yaitu beberapa mahasiswa Unma. Data dikumpulkan lewat diskusi informal dan survey lapangan, yang bertujuan mendapatkan gambaran konteks yang menjadi dasar penyusunan program arsitektur. Tim peneliti berinteraksi dengan tapak, dengan dimediasi oleh fasilitator untuk mendapatkan aneka informasi yang berguna untuk merancang fasilitas Pasar Desa di tapak tersebut. Pelibatan surveyor pada pengambilan data tahap pertama dimaksudkan agar mereka ikut memahami konteks program revitalisasi atau pengembangan Pasar Desa, terutama ketika surveyor ini akan mengambil data melalui wawancara terstruktur pada tahap kedua selanjutnya.

Survey dan diskusi untuk rencana revitalisasi Pasar Maja Utara langsung dilakukan bersama oleh peneliti, asisten peneliti, fasilitator dan Kuwu Maja Utara beserta aparat, yang juga didampingi oleh para surveyor (gambar 6). Data diambil melalui observasi lingkungan fisik pasar dan para pengguna pasar, pedagang dan pembeli, baik pada pasar harian atau pasar ternak. Peneliti berperan untuk mengarahkan tujuan rencana revitalisasi pasar. Asisten peneliti, yang juga berprofesi sebagai arsitek, banyak memberikan gagasan tentang aspek arsitektural yang bisa dikembangkan untuk revitalisasi. Kuwu dan aparat desa berperan memberikan informasi tentang kondisi pasar, memediasi antara tim peneliti dengan pedagang dan pembeli pasar, serta membuka kemungkinan sinergi kegiatan pengabdian masyarakat oleh peneliti dengan program pembangunan desa. Fasilitator berperan untuk memberikan informasi konteks yang lebih luas di Majalengka, yang relevan dengan keperluan pengabdian kepada masyarakat. Surveyor, karena mempunyai latar belakang mahasiswa peternakan, selain belajar tentang konteks pengabdian masyarakat, juga memberikan pengetahuan tentang hewan ternak di pasar kepada tim peneliti.

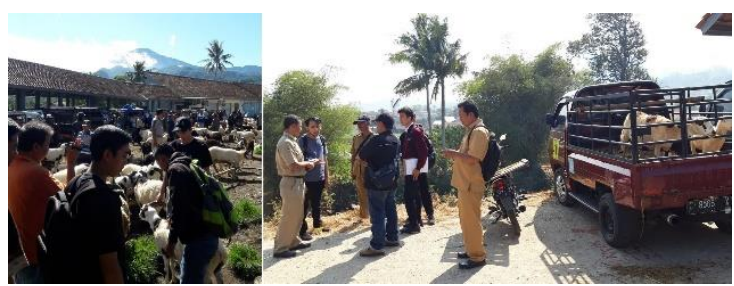

Gambar 6. Survey dan diskusi pada pengambilan data di Pasar Maja Utara

Sedangkan pengambilan data tahap pertama untuk Pasar Argapura dan Pasar Sangkan Hurip langsung pada saat survey tapak di lapangan (gambar 7). Untuk keperluan program arsitektur, informasi dari para Kuwu pada tahap 
proposal sudah memadai. Pada tahap ini, untuk Pasar Argapura dan Pasar Sangkan Hurip, fasilitator berperan penting, karena menjadi mediator antara gagasan para Kuwu dengan kegiatan penelitian, yaitu memastikan lokasi pasar yang akan dibangun, konteks permasalahan yang terkait, dan relasi-relasi yang dipunyai oleh para Kuwu dan pelaku kunci lain yang terlibat. Surveyor juga dilibatkan dalam survey lapangan pada lokasi pasar, dengan maksud supaya punya gambaran saat harus melakukan wawancara selanjutnya.

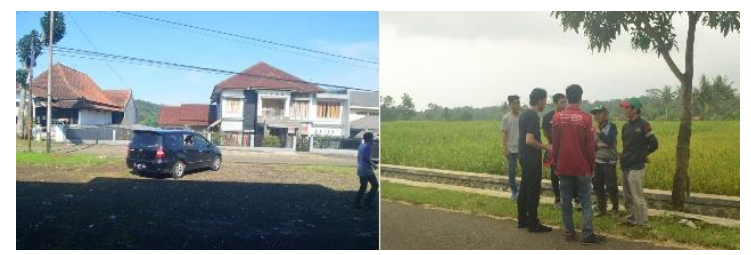

Gambar 7. Survey tapak untuk Pasar Argapura (kiri) dan Pasar Sangkan Hurip (kanan)

Pada tahap ini, pelaku yang berperan penting adalah tim peneliti dan tapak tempat pasar yang digagas akan direvitalisasi atau dikembangkan. Lewat tapak, tim peneliti bisa mengetahui secara langsung konteks permasalahan, apa saja elemen fisik dan siapa saja orang-orang yang sudah atau akan terlibat dan berperan dalam "menghidupkan" tapak tersebut. Survey langsung untuk berdialog dalam tapak dalam tradisi arsitektur dipengaruhi oleh pendekatan Fenomenologi, biarkan tapak bicara dan didengar oleh arsitek, untuk mendapatkan kecerdasan lokal (Genius Loci) dari tempat tersebut (Sharr, 2007, Norberg-Schulz, 1991). Dalam kehidupan pasar pada umumnya, Genius Loci ini berperan penting dalam hadirnya "ruh" yang menjadikan pasar rakyat hidup oleh aktivitas ekonomi dan budaya (Ekomadyo, dkk, 2012, Ekomadyo, 2012).

Selain itu, ada mediator yang berperan dalam relasi antara peneliti dan tapak pasar, yaitu fasilitator dan surveyor. Fasilitator berperan untuk menghubungkan antara kegiatan PPM dengan aspirasi para Kuwu dan pelaku kunci lain. Surveyor berperan untuk mengenali konteks permasalahan, untuk selanjutnya ditugaskan melakukan wawancara terstruktur kepada para Kuwu dan pelaku kunci lain. Secara singkat, fasilitator berperan untuk mengaitkan data-data yang didapatkan pada tahap ini dengan tahap sebelumnya, sementara surveyor berperan untuk mengaitkannya dengan data-data yang perlu ditambahkan pada tahap selanjutnya.

\subsection{Relasi-relasi pada Tahap Wawancara Terstruktur}

Seperti yang telah dijelaskan sebelumnya, konsekuensi pendekatan pro-inovasi dalam PPM adalah dirancangnya kegiatan ini sekaligus dengan dua luaran: hasil desain yang bisa dimanfaatkan oleh pengguna dan publikasi ilmiah untuk membangun jejaring dengan peneliti lainnya. Konsekuensi ini terlihat pada tahap pengumpulan data pada kegiatan PPM, di mana tahap pertama lebih bertujuan untuk desain, dan tahap kedua lebih sebagai konsekuensi ilmiah dalam produksi pengetahuan. Pada tahap kedua, data dikumpulkan dengan metode yang dipilih adalah wawancara terstruktur. Dengan kerangka Teori Jejaring Aktor, wawancara digunakan untuk menelusuri aktor-aktor yang menjadi kalkulasi para pelaku kunci dalam mengembankan inisaisi revitalisasi atau pengembangan Pasar Desa. Kerangka wawancara dibuat peneliti, dengan menerjemahkan kerangka teoretis dengan konteks penelitian dan pengabdian kepada masyarakat. Pelaku kunci yang diwawancarai dipetakan berdasarkan diskusi dengan fasilitator. Kerangka wawancara dijadikan para surveyor untuk mengambil data dari para pelaku kunci yang dipetakan (gambar 8).

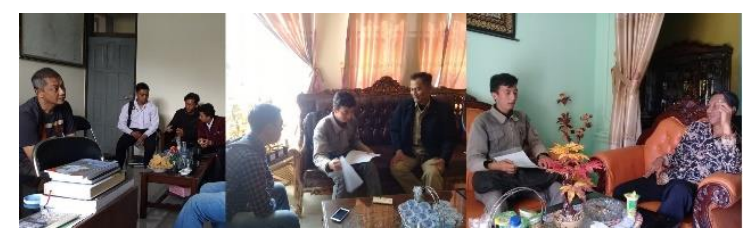

Gambar 8. Wawancara surveyor dengan pelaku kunci inisiasi revitalisasi dan pengembangan Pasar Maja Utara, Pasar Argapura, dan Pasar Sangkan Hurip

Untuk Pasar Maja Utara, pelaku kunci adalah Kuwu itu sendiri. Dari wawancara terstruktur, terpetakan bahwa permasalahan pasar muncul dari Kuwu sebelumnya yang kurang transparan dalam pengaturan kepemilikan kios. Hal ini memberikan dampak bahwa kurang dekatnya relasi antara pedagang pasar dengan aparat desa, karena masih ada kecurigaan. Namun demikian, di desa ini Kuwu punya banyak kerabat yang punya silsilah dengan KuwuKuwu yang pernah memimpin desa ini di masa 
lampau. Hal ini merupakan bentuk modal simbolik yang bisa mempengaruhi pelakupelaku lain (Bourdieu, 2018) (Dovey, 2005). Dengan modal simbolik ini, ditambah dengan inisiasi revitalisasi Pasar Desa yang dibantu oleh peneliti, Kuwu bermaksud menata kembali ruang-ruang dagang di pasar tersebut. Bahkan kemudian tercetus gagasan untuk melakukan revitalisasi pasar dengan pihak ketiga lewat Badan Usaha Milik Desa (BUMDes) sesuai kewenangannya sebagai Kuwu.

Pada pasar Argapura, terdapat empat pelaku utama yang berperan dalam inisiasi pasar distribusi yang dikelola desa-desa dalam satu kecamatan ini. Pertama adalah Kuwu Argamukti, yang menjadi koordinator Kuwu pada Kecamatan Argapura, yang selain berkarakter wirausaha juga memimpin desa yang termasuk "kaya" sebagai pemasok hasil pertanian. Kedua, Camat Argapura, merupakan camat karier yang punya rekam jejak kepemimpinan yang baik, dan berperan sebagai simbol pemersatu para Kuwu di kecamatan yang ia pimpin. Ketiga, Sekretaris Camat, masih berusia muda dan sebelumnya menjadi pegawai di Dinas Perdagangan, berperan sebagai agen pemerintah yang mendorong para Kuwu untuk mengembangkan kewirausahaan sekaligus menjadi mediator dengan pemerintah Kabupaten Majalengka. Keempat, Kuwu Sukasari Kaler, yang akan menjadi "tuan rumah" pasar Argapura, karena lokasi desa yang lebih dekat dengan jalan raya utama dan juga dekat dengan kantor kecamatan. Meskipun karakter wirausahanya tidak sekuat Kuwu Argamukti, namu Kuwu Sukasari Kaler dikenal punya kepemimpinan yang mengakar dan mempunyai penerimaan tinggi pada masyarakat setempat. Soliditas antara aparat dan KuwuKuwu di kecamatan Argapura dipicu oleh kesadaran adanya kekuatan ekonomi utama yang dipunyai kawasan ini, yaitu sebagai daerah penghasil sayur-sayuran dengan skala nasional, dan adanya kawasan wisata unggulan terutama Terasering Panyaweuyan. Program Gubernur Jawa Barat untuk membangun wisata di Kabupaten Majalengka khususnya Terasering Panyaweuyan menjadi pemicu bergeraknya para pelaku kunci untuk mengembangkan kawasan ini. Merespon potensi dan peluang ini, semua Kuwu di wilayah kecamatan Argapura, di dalam koordinasi aparat kecamatan, bersepakat membentuk BUMDes bersama.

Untuk Pasar Sangkan Hurip, terpetakan ada 4 pelaku kunci yang diperkirakan akan berpengaruh dalam tindak lanjut gagasan pengembangan Pasar Desa. Mereka Kuwu Pasir Ayu, sebagai Koordinator Kuwu dalam kecamatan, Kuwu Sangkar Hurip yang sudah bersedia menyediakan tanah desa untuk dibangun pasar, Kuwu Sindang, yang memimpin desa di pusat Kecamatan Sindang, dan Camat Sindang, sebagai aparat pemerintah kabupaten yang memimpin kecamatan. Namun dalam wawancara para pelaku, terpetakan bahwa ternyata para pelaku kunci tersebut belum sepenuhnya satu suara untuk membangun Pasar Desa di wilayah ini. Inisiasi Pasar Desa oleh Kuwu Pasir Ayu ternyata hanya didukung oleh Kuwu Sangkan Hurip, namun belum didukung oleh Kuwu-Kuwu lain terutama Kuwu Sindang. Di desa Sindang, saat ini sudah ada embrio pasar berupa sekumpulan kios, dan Kuwu Sindang memilih mempertahankan fasilitas ini daripada mengembangkannya menjadi Pasar Desa, apalagi jika berlokasi di desa lain. Karena masih ada perbedaan pendapat di antara para Kuwu, maka camat pun lebih memilih bersikap netral.

Dalam tahap wawancara terstruktur, yang berperan penting adalah kerangka survey, surveyor, dan para pelaku kunci yang diwawancarai, serta transkrip wawancara. Dalam pembuatan kerangka survey, peneliti berperan dalam menentukan substansi wawancara, sementara fasilitator berperan dalam menentukan siapa-siapa saja yang diwawancara. Dalam perspektif kolektif aktor manusia dan non-manusia (Latour, 1999), kerangka penelitian ini menjadi delegasi bagi peneliti dan fasilitator kepada para surveyor dalam membangun koneksi tentang para pelaku kunci beserta relasi-relasinya untuk inisiasi Pasar Desa. Pendelegasian merupakan tahap terakhir setelah tahap interferensi, komposisi, dan penyatuan ruang dan waktu dalam kolektif manusia dan non-manusia. Selain kerangka wawancara, ada objek teknis lain yang berperan adalah transkrip wawancara, yang menjadi delegasi surveyor untuk melaporkan hasil wawancaranya kepada peneliti. Berbeda dengan data yang terkumpul pada tahap 
pertama yang lebih berorientasi pada pemecahan masalah lewat desain, data yang terkumpul pada tahap kedua lebih bersifat untuk mendapatkan pengetahuan secara terstruktur selayaknya kegiatan penelitian ilmiah. Karena basis teori yang digunakan adalah ANT, maka transkrip wawancara berisi data-data yang mengungkap relasi-relasi yang ada pada pelaku kunci dalam inisiasi revitalisasi dan pengembangan Pasar Desa.

Meski awalnya ditujukan untuk kepentingan publikasi ilmiah, temuan pada tahap wawancara terstruktur ternyata mengungkap jejaring para pelaku kunci yang tidak terlihat pada tahaptahap sebelumnya. Bagi peneliti, temuan ini menjadi penting sebagai masukan untuk mengembangkan strategi implementasi beserta para pelaku kunci nanti. Pendekatan ANT, yang melihat bahwa sosial sebagai sesuatu yang terus bergerak (Latour, 2005) membantu peneliti untuk membaca lintasan-lintasan (trajectories) dalam jejaring yang ada agar dapat memperkirakan dan mengantisipasi perubahanperubahan yang terjadi dengan melacak lintasan-lintasan tersebut.

\subsection{Relasi-relasi pada Tahap Proses dan Hasil Desain}

Tahap ini sebenarnya merupakan tahap desain arsitektur secara konvensional. Secara umum, kegiatan perancangan dilakukan dalam 4 tahap: 1) pemrograman arsitektur, yaitu menerjemahkan informasi yang didapatkan dalam tahap diskusi informal dan survey lapangan ke dalam program arsitektur, 2) desain skematik, yaitu mengembangkan aneka alternatif gagasan desain secara bebas dan kreatif, 3) konsultasi desain, yaitu mengkomunikasikan hasil desain kepada para pemangku kepentingan untuk disempurnakan dan, dan 4) hasil desain yang dipresentasikan secara grafis. Namun sebagai konsekuensi dari situasi pro-inovasi, proses dan hasil desain bukan sekadar ditujukan untuk menyelesaikan permasalahan, tetapi sarana untuk memproduksi pengetahuan secara terstruktur. Desain di sini dilihat sebagai upaya pemecahan masalah sekaligus sebagai proses belajar, dan ini menjadi bagian dari upaya membangun desain sebagai disiplin berbasis pengetahuan dari tradisi berbuat untuk mendapatkan kecocokan antara gagasan dan praktik (Archer,
1979) (Cross, 1982) (Dilnot, 1982) (Dorst, 2003) (Saliya, 2003) (Ekomadyo, 2013). Khusus untuk kegiatan penelitian ini, ekstraksi pengetahuan dilakukan dengan kerangka Teori Jejaring Aktor/ ANT. Dengan teori ini, maka proses desain akan dilihat relasi-relasi yang terjadi antara aktor manusia dan aktor non manusia (Ekomadyo \& Yuliar, 2015).

Tahap pemrograman adalah tahap untuk merumuskan masalah yang direspon dalam desain berdasarkan data-data yang diperoleh saat survey dan diskusi dengan para pelaku kunci. Pada tahap ini ada 3 aktor yang berperan penting, yaitu peneliti, yang berperan dalam membaca dan menginterpretasi aneka aspirasi untuk mengarahkan hasil akhir desain, anggota peneliti, yang berperan dalam mengelaborasi aspek konstruksi dan materialitas dalam desain fasilitas pasar, dan asisten peneliti, seorang arsitek profesional yang berperan menerjemahkan semua gagasan dalam hasil desain. Pada tahap ini, beberapa preseden desain dan material digunakan untuk menentukan pendekatan desain dan fasilitas yang akan disediakan. Dalam beberapa diskusi, muncul gagasan untuk membuat ruang-ruang komunal dalam pasar, dengan preseden adalah Bale Pasar yang pada beberapa Pasar Desa di Bali, yang untuk pasar di Majalengka ditransformasikan sebagai Saung Pasar. Identitas lokal dicapai dengan eksplorasi materialitas genting dan batu bata, merujuk pada karakter industri genting yang ada di daerah Majalengka. Untuk pasar yang baru, fasilitas yang akan disediakan adalah los-los berjajar yang terbuka, merujuk pada beberapa Pasar Desa di Jawa Tengah (gambar 9 dan 10).

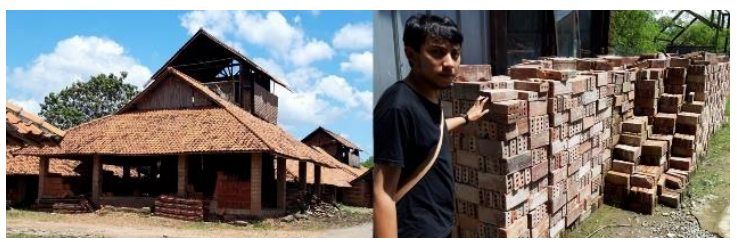

Gambar 9. Materialitas lokal, genting dan batu bata, yang diangkat sebagai karakter desain Pasar Desa

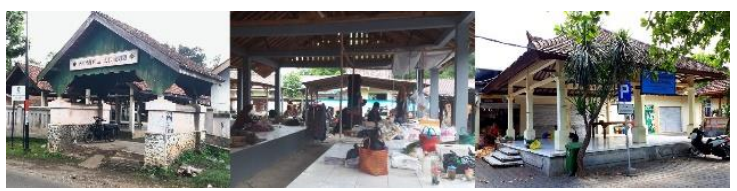

Gambar 10. Beberapa preseden pasar yang menjadi rujukan desain Pasar Desa 
Tahap desain skematik merupakan kegiatan internal tim peneliti untuk mengembangkan aneka gagasan desain yang cocok untuk menjawab permasalahan desain yang telah dirumuskan dalam tahap pemrograman. Selain tim peneliti, beberapa mahasiswa arsitektur dilibatkan, selain untuk membantu asisten peneliti, juga sebagai bagian dari proses pembelajaran akademis. Selain aktor-aktor manusia, aneka media gambar menjadi aktor non-manusia yang berperan penting dalam interaksi antar pelaku manusia. Proses berkembangnya gagasan bisa dilacak dari produk-produk gambar yang dihasilkan (gambar 11).

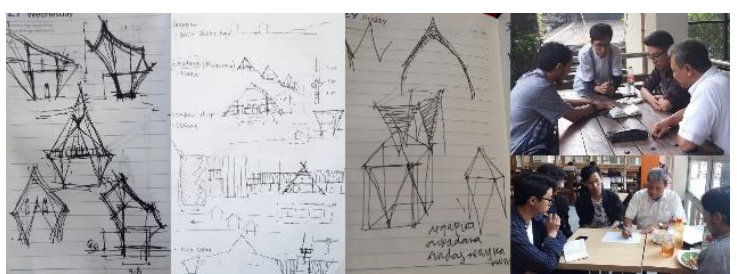

Gambar 11. Suasana diskusi internal tim peneliti dan beberapa artefak gambar yang dihasilkan dalam proses desain

Untuk mendapatkan penerimaan dari pengguna desain, perlu ada konsultasi desain dengan para pemangku kepentingan. Pada tahap ini, pelaku kunci adalah peneliti dan asisten peneliti, yang dengan pengalaman praktisnya menyampaikan hasil dari proses desain untuk mendapatkan masukan. Upaya konsultasi dilakukan dengan cara informal, menyesuaikan suasana pemangku kepentingan Pasar Desa (gambar 12).

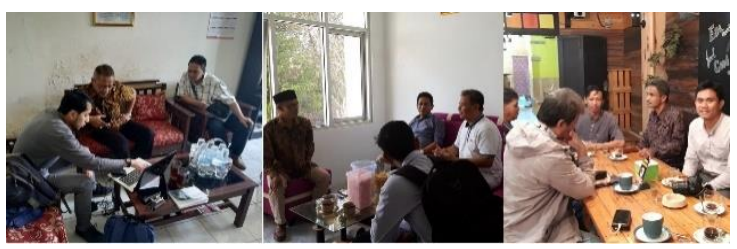

Gambar 12. Suasana konsultasi desain Pasar Maja Utara (kiri), Pasar Argapura (tengah), dan Pasar Sangkan Hurip (kanan)

Hasil desain berupa rancangan Pasar Desa (gambar 11). Untuk Pasar Maja Utara, dihasilkan rancangan Saung Pasar, agar komunitas pasar bisa berkumpul dan berembug bersama untuk upaya perbaikan atau revitalisasi pasar yang ada. Untuk Pasar Argapura dan Pasar Sangkan Hurip, dihasilkan rancangan bangunan pasar yang baru pada tapak pasar yang diusulkan. Konsep utamanya adalah merancang pasar berupa bangunan dengan loslos yang tipikal, dengan tengaran berupa saung pasar yang merefleksikan karakter materialitas lokal Majalengka.
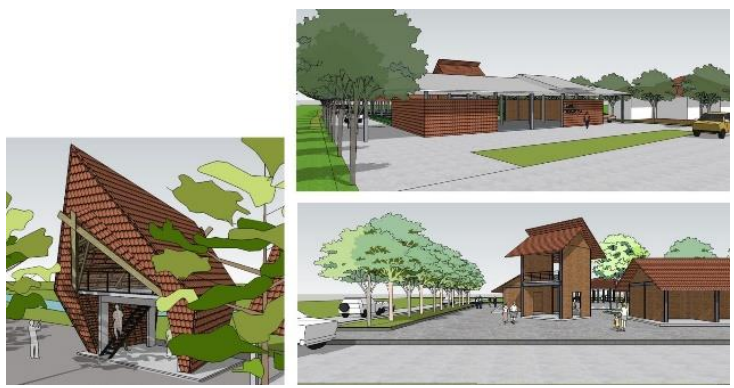

Gambar 13. Hasil desain Pasar Maja Utara, Pasar Argapura, dan Pasar Sangkan Hurip

Dalam tahap proses dan hasil desain, perspektif ANT memberikan gambaran bagaimana kolektivitas hadir dalam proses desain. ANT memberikan istilah kolektif untuk menunjukkan bahwa suatu fenomena sosial dilihat bagaimana aktor manusia dan aktor manusia mengumpul dan terkumpul (to collect and to be collected) lewat momentummomentum tertentu, dan relasi-relasi ini terus bergerak, namun bisa dibingkai pada beberapa momentum tertentu untuk dibaca dan diurai relasi-relasi yang muncul (Latour, 1999). Pendekatan kolektif ini bisa menyempurnakan pendekatan konvensional untuk desain partisipatif (Andersen et al., 2015) (Storni, et al, 2015) (Storni, 2015) (Rice, 2018), karena pada hakikatnya setiap proses desain adalah partisipatif, tergantung siapa saja, pada momentum apa, dan sejauh mana partisipasi tersebut dilakukan. Melalui pendekatan kolektif, perancang - dalam kegiatan dilakukan tim peneliti- tidak harus berhadapan langsung dengan pengguna hasil desain -karena bisa jadi pengguna belum mengerti tentang tujuan desain- namun bisa dimediasi oleh para pelaku kunci -dalam hal ini para Kuwu- yang lebih bisa menyampaikan gagasan desain sesuai dengan bahasa sehari-hari pengguna desain yaitu pelaku pasar dan masyarakat desa. Dalam proses desain, gambar-gambar desain merupakan aktor non manusia yang berperan penting sebagai mediator dalam penyampaian gagasan dan aspirasi antara pelaku yang terlibat. Perhatian ANT pada proses desain adalah melihat relasi-relasi yang terjadi antara aktor manusia dan aktor non-manusia. 


\subsection{Relasi-relasi pada Tahap Rekonfirmasi Hasil Desain}

Tahap rekonfirmasi hasil desain dilakukan dengan mempresentasikan hasil desain kepada para pelaku kunci revitalisasi dan pengembangan Pasar Desa. Presentasi dilakukan oleh peneliti dengan suasana informal, menyesuaikan dengan suasana masyarakat desa (gambar 13). Tujuan utama rekonfirmasi hasil desain adalah menyusun strategi implementasi desain, terutama oleh para Kuwu dan pelaku kunci lainnya, setelah hasil desain diserahkan oleh tim peneliti. Namun selain itu, untuk keperluan produksi pengetahuan, proses rekonfirmasi hasil desain juga dilakukan untuk membaca hasil pembelajaran yang terjadi dalam proses desain dengan mengidentifikasi penambahan pengetahuan yang terjadi pada pelaku-pelaku yang terlibat. Dengan perspektif ANT, penambahan pengetahuan ini ditandai dengan perluasan jejaring, terutama jejaring untuk aneka aktivitas inovasi, yang akan terjadi setelah proses PPM selesai.

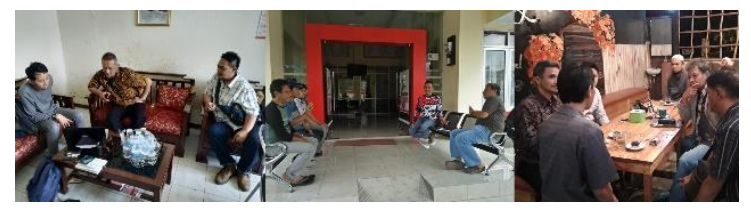

Gambar 14. Suasana rekonfirmasi desain untuk Pasar Maja Utara, Pasar Argapura, dan Pasar Sangkan Hurip

Untuk Pasar Maja Utara, ada beberapa strategi implementasi untuk menindaklanjuti hasil desain. Pertama, sharing pembiayaan pembangunan Saung Pasar antara kegiatan pengabdian kepada masyarakat dari tim peneliti dengan dana desa di bawah kewenangan Kuwu. Kedua, melihat dukungan tim peneliti untuk revitalisasi Pasar Desa, Kuwu Maja Utara memutuskan untuk mengembangkan inisiasi ini dengan skema kemitraan dengan swasta. Kedua strategi implementasi ini menunjukkan inisiasi revitalisasi Pasar Desa Maja utara menunjukkan perluasan jejaring inovasi. Hasil desain mendorong Kuwu untuk mengembangkan aneka kegiatan yang bercorak kewirausahaan, dan kalau ini berlangsung maka peneliti bisa melanjutkan pendampingan agar inisiatif dan desain bisa dilaksanakan sesuai dengan yang diharapkan.
Untuk pasar Argapura, rekonfirmasi desain melibatkan pelaku-pelaku lain selain inisiator awal yaitu Kuwu Argamukti. Gagasan untuk membentuk BUMDes Bersama se-Kecamatan Argapura mendorong inisiasi Pasar Argamukti sebagai pasar distribusi sebagai salah satu unit usaha yang akan diunggulkan. Dalam skema bisnis BUMDes bersama ini, keberadaan Pasar Argapura akan digabungkan dengan sarana dan prasarana wisata di kawasan ini. Hal ini menunjukkan terjadinya perluasan jejaring inovasi, yang awalnya hanya melibatkan satu Kuwu namun di akhir bisa menghela beberapa pelaku kunci lain: Kuwu lain, aparat kecamatan, dan direksi BUMDes Bersama. Desain pasar menjadi bagian dalam upaya pengembangan kewirausahaan di tingkat kecamatan.

Untuk Pasar Sangkan Hurip, dalam rekonfirmasi desain ternyata para Kuwu memilih untuk menunda dulu implementasi inisiasi gagasan Pasar Desa. Inisiator, yaitu Kuwu Pasir Ayu, lebih memilih untuk melakukan konsolidasi internal, terutama mengatasi perbedaan pendapat dengan KuwuKuwu lain. Hal ini membutuhkan proses yang panjang karena terkait dengan relasi-relasi politik lokal di antara para Kuwu. Namun demikian, jejaring inovasi antara inisiator, yaitu Kuwu Pasir Ayu, dengan peneliti tetap dipertahankan, namun dengan kegiatan penelitian lain selain Pasar Desa. Jejaring inovasi pada penelitian Pasar Desa Sangkan Hurip ternyata tidak meluas setelah penelitian selesai. Ada faktor-faktor internal di desa yang harus diselesaikan dan tidak memerlukan kehadiran peneliti.

Dari tiga kasus di atas, terlihat ada jejaring yang meluas dan yang tidak meluas setelah kegiatan PPM selesai. Jejaring yang meluas terjadi pada Pasar Maja Utara dan Pasar Argapura: hasil desain akan ditindaklanjuti oleh pelaku kunci lokal dengan semangat kewirausahaan. Keterlibatan peneliti akan memegang peran penting bagi pelaku lokal terutama dalam mengembangan jejaring kewirausahaan yang akan dibangun. Sedangkan jejaring yang tidak meluas terjadi pada Pasar Sangkan Hurip. Pilihan untuk menyelesaikan permasalahan internal sebagai tindak lanjut tidak memerlukan peran peneliti. 
Dari rangkuman perluasan jejaring inovasi di atas, ada dua hal yang mendorong perluasan jejaring inovasi pasca kegiatan PPM selesai. Pertama, soliditas pelaku lokal. Soliditas pada pasar Maja Utara ditentukan oleh kepemimpinan dari Kuwu setempat sebagai pemilik otoritas pengelolaan pasar. Sedangkan soliditas pasar Argapura ditentukan oleh visi bersama untuk pengembangan kawasan merespon potensi dan peluang yang dimiliki desa-desa di kecamatan ini.

Faktor kedua adalah jejaring yang dimiliki peneliti. Ketika para pelaku lokal akan menindaklanjuti hasil desain dengan semangat kewirausahaan, maka peneliti akan bisa berperan sebagai mediator terutama untuk memperluas jejaring lokal dengan jejaring pada tingkat provinsi maupun nasional. Rekam jejak peneliti dalam program revitalisasi pasar rakyat diharapkan mampu membangun sinergi antara inisiatif lokal pada tingkat desa dengan program nasional maupun provinsi Jawa Barat. Artinya perluasan jejaring inovasi bukan saja ditentukan oleh pengetahuan, namun juga jejaring yang dimiliki oleh peneliti. Dengan perspektif ANT, pengetahuan yang dimiliki peneliti adalah bagian dari jejaring, dan jejaring ini lebih memberikan dampak munculnya inovasi-inovasi dalam tingkat lokal pada kasus yang diteliti.

\section{PEMBAHASAN}

Dari pemetaan relasi-relasi antarpelaku dalam tiap tahap kegiatan PPM ini, ada beberapa hal penting yang menjadi temuan. Pertama, adanya ekosistem lokal untuk inovasi dalam pembangunan desa, yang mendorong tumbuhnya aneka gagasan inovasi, yang kemudian mendorong bertemunya peneliti dalam lingkup non-lokal (nasional/ internasional) dengan pelaku-pelaku lokal. Untuk kasus PPM Pasar Desa di Majalengka, ekosistem ini dibentuk oleh beberapa Kuwu yang mempunyai visi kuat dan berpikiran progresif, yang terajut untuk membangun hubungan saling menguntungkan antar sesama mereka, yang didukung oleh keberadaan fasilitator bersertifikat nasional dan civitas universitas setempat. Forum ini yang banyak memicu aneka gagasan inovasi di desa, dan salah satunya bisa terhubung dengan program PPM dari peneliti.
Kedua, konsekuensi dari pendekatan situasi pro-inovasi menjadikan kegiatan PPM ini mempunyai dua misi: membantu penyelesaian permasalahan lokal yang dihadapi mitra PPM, dan kegiatan produksi pengetahuan secara ilmiah. Konsekuensi ini tercermin dalam aneka tahap penelitian, yang beberapa diantaranya dilaksanakan dengan dua tujuan, yaitu mengumpulkan informasi untuk keperluan desain pasar dan strategi implementasinya, dan mengumpulkan data secara ilmiah dengan kerangka teori yang digunakan. Dalam pelaksanaannya, keduanya berjalan secara simultan dan saling mempengaruhi.

Ketiga, konsekuensi penggunaan teori jejaring aktor adalah pelaksanaan desain secara kolektif. Desain kolektif merupakan penyempurnaan dari desain partisipatif, karena pada hakikatnya setiap proses desain adalah partisipatif tergantu siapa, kapan, dan bagaimana cara partisipasi dari pelaku-pelaku yang terlibat. Dengan pendekatan ANT, maka pelaku-pelaku yang terlibat bisa dipilih, dalam bahasa ANT-nya disebut dibingkai (to be framed), siapa yang terlibat dan kapan, dengan kerangka tujuan dari desain.

Keempat, dari tiga kasus Pasar Desa yang diteliti, ternyata ada yang menunjukkan perluasan jejaring inovasi dan ada yang tidak. Jejaring yang meluas terjadi pada PPM di di Pasar Maja Utara dan Pasar Argapura, yang tidak meluas terjadi pada Pasar Sangkan Hurip. Ada dua faktor yang mendorong perluasan jejaring: faktor internal yaitu soliditas pelaku lokal dan faktor eksternal yaitu jejaring peneliti.

Dari tersebut, ada tiga hal hal yang bisa digeneralisasi untuk membaca peran penelitian/ pengabdian masyarakat Perguruan Tinggi untuk mendorong inovasi desa. Pertama adalah ekosistem inovasi eksisting yang sudah terbangun di perdesaan, yang mampu menciptakan aneka interaksi dengan pihak luar, termasuk Perguruan Tinggi, untuk memicu gagasan pengembangan dan inovasi. Kedua, keberadaan mediator lokal, yang mampu menjembatani "dunia desa" dan "dunia universitas". Dalam kasus ini, peran mediator ini dilakukan oleh fasilitator nasional yang tinggal di daerah dan universitas lokal yang mempunyai sumber daya akademis yang masih menjadi bagian dari "dunia desa". Ketiga, 
jejaring yang dimiliki peneliti dari Perguruan Tinggi. Artinya, dampak terhadap berkembangnya inovasi di perdesaan tidak melulu digerakkan oleh pengetahuan yang dimiliki oleh peneliti, tetapi juga bagaimana pengetahuan itu menjadi bagian dari jejaring Perguruan Tinggi, sehingga para pelaku inovasi di desa bisa memanfaatkan jejaring tersebut untuk pengembangan inovasi desa. Dalam perspektif pro-inovasi, kehadiran Perguruan Tinggi bukan sekadar sebagai agen yang memberikan pengetahuan, tetapi bagaimana pengetahuan ini menjadi jejaring yang dimanfaatkan masyarakat desa untuk berkembang, sehingga kegiatan inovasi di perdesaan tetap berlanjut meski kegiatan PPM telah selesai.

\section{KESIMPULAN}

Dengan mengambil kasus PPM pada beberapa Pasar Desa di Majalengka, ada beberapa temuan penting bagaimana situasi pro-inovasi bisa terjadi. Pertama, adanya ekosistem inovasi lokal, yaitu adanya forum para Kuwu yang bersama-sama ingin membangun wilayahnya, yang memicu aneka gagasan inovasi yang berpotensi melibatkan pihak luar desa termasuk peneliti dari universitas. Kedua, adanya mediator yang berperan dalam menjembatani "dunia universitas" dengan "dunia desa", dalam kasus ini peran ini dilakukan oleh fasilitator setempat yang bersertifikat nasional dan civitas universitas setempat yang terlibat dalam forumforum Kuwu. Ketiga, perluasan jejaring inovasi setelah kegiatan PPM terjadi jika ada faktor internal, yaitu soliditas pelaku kunci inovasi di desa, dan faktor eksternal, yaitu jejaring yang dimiliki peneliti yang bisa dimanfaatkan pelaku inovasi di desa untuk mengembangkan potensi yang ada. Temuan ketiga ini menjadi penting, karena ternyata bukan sekadar pengetahuan dari peneliti yang berperan penting untuk keberlanjutan inovasi di perdesaan, tetapi lebih pada jejaring Perguruan Tinggi, di mana pengetahuan merupakan bagian dari jejaring tersebut.

Dengan pendekatan pro-inovasi, maka kegiatan PPM di perdesaan perlu dirancang sebagai bagian dari penyelesaian masalah sekaligus produksi pengetahuan secara ilmiah. Di sini, kemampuan berpikir design (design thinking) menjadi penting, terutama kemampuan dalam membingkai (framing) cara dan nilai-nilai dalam suatu tindakan dalam satu pemikiran sekaligus (Dorst, 2011). Untuk kasus PPM di Majalengka, ketercapaian situasi pro-inovasi dirancang melalui tahap pengumpulan data yang mempunyai dua misi: menggali permasalahan untuk dicari penyelesaiannya dan mengumpulkan informasi secara terstruktur secara ilmiah. Biasanya, kegiatan Perguruan Tinggi di desa lebih berorientasi pada hal-hal yang bersifat aplikatif karena bisa dimanfaatkan langsung oleh masyarakat. Namun dengan pendekatan situasi pro-inovasi, kegiatan riset ilmiah berbasis teori tertentu perlu dirancang sebagai bagian upaya pemecahan masalah tersebut, agar pengetahuan yang didapatkan dalam upaya tersebut dapat diekstraksi dan dipublikasikan dalam forumforum ilmiah.

Secara lebih luas, pendekatan pro-inovasi untuk pengembangan dan keberlanjutan inovasi di perdesaan memanggil kembali peran Perguruan Tinggi sebagai agen perubahan (agent of change) terhadap masyarakat (Doring, 2010) (Peer \& Stoeglehner, 2020). Dalam kerangka inovasi, peran Perguruan Tinggi sebagai "entrepreneurial university" didasarkan pada pemikiran perlunya pergeseran peran Perguruan Tinggi untuk masuk ke dalam realitas masyarakat dan berkontribusi dalam membangun ekosistem inovasi, tidak lagi sebagai "menara gading" (ivory tower) yang luhur namun berjarak (Etzkowitz et al., 2000). Di sini, keluhuran peran Perguruan Tinggi didapatkan dari nilai-nilai yang diakumulasikan dari berbagai pengetahuan ilmiah yang diekstraksi dari kerja-kerja inovasi dalam merespon permasalahan nyata di masyarakat. Dengan pendekatan situasi pro-inovasi, maka cita-cita Perguruan Tinggi Kelas Dunia (PKTD) di Indonesia dibangun dengan memproduksi pengetahuan-pengetahuan yang dibutuhkan masyarakat dunia yang didapatkan ketika para peneliti turut berperan dalam menyelesaikan permasalahan bangsa.

\section{REFERENSI}

Althaf, N. A. (2019). IMPLEMENTASI CIVIC RESPONSIBILITY DALAM PENGADAAN TANAH OLEH NEGARA: Studi Desksriptif pada Pembangunan Bandar Internasional di Desa Sukakerta 
Kabupaten Majalengka (Doctoral dissertation, Universitas Pendidikan Indonesia).

Andersen, L. B., Danholt, P., Halskov, K., Hansen, N. B., \& Lauritsen, P. (2015). Participation as a matter of concern in participatory design. CoDesign, 11(3-4), 250-261.

Annisaa, D. M., \& Widhi, H. (2018). PENGADAAN

TERHADAP TANAH

PEMBANGUNAN PELAKSANAAN $B A N D A R A$ INTERNASIONAL BERBASIS NILAI KEADILAN SOSIAL (Studi di Kecamatan Kertajati Kabupaten Majalengka Provinsi Jawa Barat) (Doctoral dissertation, Fakultas Hukum UNDIP).

Archer, B. (1979). Design as a discipline. Design studies, 1(1), 17-20.

Arumsari, N., Septina, W. E., Luthfi, M., \& Rizki, N. K. A. (2017). Komunikasi politik kepala desa dalam mendorong inovasi pembangunan desa: Studi kasus tiga desa di lereng gunung Ungaran, Jawa Tengah. Politik Indonesia: Indonesian Political Science Review, 2(1), 86-99.

Barki, K., Satmoko, S., \& Eddy, B. T. (2017). Pengaruh modal sosial terhadap tingkat adopsi inovasi padi organik pada anggota kelompok tani paguyuban al-barokah, Desa Ketapang, Kecamatan Susukan, Kabupaten Semarang. AGROMEDIA: Berkala Ilmiah Ilmu-ilmu Pertanian, 35(2).

Basri, M. C. (2012). Rumah Ekonomi Rumah Budaya. Gramedia Pustaka Utama.

Cross, N. (1982). Designerly ways of knowing. Design studies, 3(4), 221-227.

Damayanti, Y., Krisnani, H., \& Budiarti, M. (2017). Keberadaan Masyarakat Pendatang di Desa Sukakerta (Perubahan Sosial Budaya Masyarakat terkait Pembangunan Bandara Internasional Jawa Barat di Kecamatan Kertajati, Kabupaten Majalengka). Prosiding Penelitian dan Pengabdian kepada Masyarakat, 3(1).

Dilnot, C. (1982). Design as a socially significant activity: an introduction. Design Studies, 3(3), 139146.

Dipojono, H. K. (2019, March 6). Sambutan Ketua Senat Akademik ITB: Dies Natalis ITB ke 60 [PDF]. Senat Akademik ITB.
Doring, A. (2002). Challenges to the academic role of change agent. Journal of further and Higher Education, 26(2), 139-148.

Dorst, K. (2011). The core of 'design thinking'and its application. Design studies, 32(6), 521-532.

Dovey, K. (2005). 14 The Silent Complicity of Architecture. Habitus: A sense of place, 283.

Duerk, D. P. (1993). Architectural programming: Information management for design. Van Nostrand Reinhold Company.

Ekomadyo, A. S. (2012). Menelusuri genius loci pasar tradisional sebagai ruang sosial urban di Nusantara. Semesta Arsitektur Nusantara.

Ekomadyo, A. S. (2019). Evaluating Revitalized Public Markets as Economic and Socio-cultural Places in Indonesia. Pertanika Journal of Social Sciences \& Humanities, 27(2).

Ekomadyo, A. S. (2019). Teori Desain Arsitektur. ITB Press.

Ekomadyo, A. S., \& Hidayatsyah, S. (2012). Isu, Tujuan, dan Kriteria Perancangan Pasar Tradisional. Prosiding Temu Ilmiah IPLBI, 1.

Ekomadyo, A. S., Zahra, A., \& Najmi, I. (2012, July). Public Market as Urban Social Nodes: An Architectural Phenomenology Approach. In Arte-Polis 4 International Conference-Creative Connectivity and the Making of Place.

Ekomadyo, A., \& Yuliar, S. (2015). Social reassembling as design strategies. Procedia-Social and Behavioral Sciences, 184, 152-160.

Etzkowitz, H. (2008). The triple helix: University-industry-government innovation in action. Taylor \& Francis.

Etzkowitz, H., Webster, A., Gebhardt, C., \& Terra, B. R. C. (2000). The future of the university and the university of the future: evolution of ivory tower to entrepreneurial paradigm. Research policy,29(2), 313330.

Febriana, K. A., \& Setiawan, Y. B. (2016). Komunikasi dalam Difusi Inovasi Kerajinan Enceng Gondok di Desa Tuntang, Kabupaten Semarang. Jurnal The Messenger, 8(1), 17-26. 
Granovetter, M. (2018). The sociology of economic life. Routledge.

Hidayat, E., Sutandi, A., \& Tjahjono, B. (2014). Kajian wilayah pengembangan industri kecil berbasis komoditas unggulan pertanian di Kabupaten Majalengka. Majalah Ilmiah Globë, 16(2).

INDONESIA, P. R. Undang-Undang Republik Indonesia Nomor 6 Tahun 2014 Tentang Desa.

Jimika, F. (2019). Dampak Pembangunan Bandara Kertajati terhadap Struktur Perekonomian Majalengka. Maro: Jurnal Ekonomi syariah dan Bisnis, 2(1), 11-21.

Latour, B. (2005). Reassembling the social: An introduction to actor-network-Theory. Oxford University Press.

Latour, B. (2009). A collective of humans and nonhumans: Following Daedalus's labyrinth. Readings in the Philosophy of Technology, 11 .

Nursetiawan, I. (2018). Strategi pengembangan desa mandiri melalui inovasi bumdes. MODERAT: Jurnal Ilmiah Ilmu Pemerintahan, 4(2), 72-81.

Palmer, M. A. (1981). The Guide to Facility Programming. Washington DC: The American Institute of Architects.

Peer, V., \& Stoeglehner, G. (2013). Universities as change agents for sustainabilityframing the role of knowledge transfer and generation in regional development processes. Journal of Cleaner Production, 44, 85-95.

Peña, W., Caudill, W. W., \& Focke, J. (1977). Problem seeking: An architectural programming primer.

Rice, L. (2018). Nonhumans in participatory design. CoDesign, 14(3), 238-257.

Saliya, Y. (2003). Perjalanan Malam Hari.

Salmi, J. (2009). The challenge of establishing world class universities. The World Bank.

Schulz, C. N. (1980). Genius loci: Towards a phenomenology of architecture. Academy Editions, London.

Sharr, A. (2007). Heidegger for architects. Routledge.

Storni, C. (2015). Notes on ANT for designers: ontological, methodological and epistemological turn in collaborative design. CoDesign, 11(3-4), 166-178.

Storni, C., Binder, T., Linde, P., \& Stuedahl, D. (2015). Designing things together: intersections of co-design and actornetwork theory.

Sururi, A., \& Mulyasih, R. (2017). Pemberdayaan Masyarakat melalui Inovasi Perencanaan Pembangunan berbasis 4R (Rembug, Rencana, Realisasi dan Rawat) di Desa Cilangkap Kecamatan Wanasalam sebagai Pilar Utama Kebijakan Partisipatif dan Gotong Royong. Engagement: Jurnal Pengabdian Kepada Masyarakat, 1(2), 218-238.

Yuliar, S. (2009). Tata Kelola Teknologi: Perspektif Teori Jaringan Aktor. Penerbit ITB.

Yuliar, S. (2011). Transformasi Penelitian ke dalam Inovasi. Jakarta: Dewan Riset Nasional.

Yuliawati, E. (2017). Modal Share Dalam Demand Forecasting di Bandara Internasional Jawa Barat (BIJB) Kertajati Majalengka. Warta Ardhia, 42(4), 173184.

Zulfikar, W. (2017). Dampak Sosial, Ekonomi Dan Politis Dalam Pembangunan Bandara Udara Kertajati Di Kabupaten Majalengka. Creative Research Journal, 3(01), 13-24. 